\title{
Influence of trace elements in the epigenetic of mammals
}

\author{
Lia Celina Méndez-Rodríguez ${ }^{1 *}$ and Sergio Ticul Álvarez-Castañeda ${ }^{1}$
}

Introduction: Chronic exposure to toxic levels of elements such as arsenic, cadmium, lead, mercury, nickel and others trace elements might cause abnormalities in gene expression affecting metabolic pathways such as those related to trace elements detoxification and the reproductive ability of animals. Rodent species have been the subject of several studies examining the physiological consequences of exposure to toxic levels of arsenic, cadmium and nickel, and how those elements affect their epigenetic mechanisms such as DNA methylation. Results from those studies can be used as an approach of the effects that can potentially occur on small mammals found in sites altered by geochemical or anthropogenic activities (e. g. mining, industrial waste).

Methods: An exhaustive literature review was conducted aimed to gain a better understanding of epigenetics, identifying mechanisms involved in the toxicity of trace elements, elucidating the effect of those trace metals in the epigenetics of genes involved in detoxification mechanisms and, finally, determining whether damages caused by exposition to high levels of trace elements are equally evident on any tissue from the same organism.

Results and Discussion: Pollutants can influence methylation of DNA patterns, but not all of them follow the same pathway. This varies widely among groups of trace elements or organic compounds. In addition to concentration and time of exposure, a number of other factors affect the toxicity pathway, including age, sex, food sources and, especially, the physiology of the species. Even within the same organism, the methylation patterns associated to a given element vary between tissues. Therefore, selecting the most appropriate tissue for discerning the animal's actual condition is key when assessing the actual health status of wildlife species. Further studies are needed to better characterize the interactions between DNA methylation and trace elements, and elucidate potential mechanisms or interventions that can help to reduce their effects on wildlife health.

Key words: ADN methylation, gene, pollution, trace elements, toxicity.

\section{Resumen}

La exposición crónica a niveles tóxicos de elementos como arsénico, cadmio, plomo, mercurio, níquel y otros elementos traza, puede causar alteraciones en la expresión de diversos genes afectando procesos metabólicos como los relacionados con la detoxificación de elementos traza y la capacidad reproductiva de los animales. Las especies de roedores han sido objeto de varios estudios que examinan las consecuencias fisiológicas de la exposición a niveles tóxicos de arsénico, cadmio y níquel y cómo estos elementos afectan sus mecanismos epigenéticos, tales como la metilación del ADN. Los resultados de esos estudios pueden ser utilizados como una aproximación de los efectos que potencialmente pueden ocurrir en pequeños mamíferos que se encuentran en sitios alterados por actividades geoquímicas o antropogénicas (por ejemplo, minería, residuos industriales).

Se llevó a cabo una exhaustiva revisión de la literatura con objeto de lograr una mejor ${ }^{1}$ Centro de Investigaciones Biológicas del Noroeste S. C. Instituto Politécnico Nacional 195. La Paz, 23096. Baja California Sur, México. Email: Imendez04@cibnor.mx (LCMR), sticul@cibnor.mx (STAC)

${ }^{*}$ Corresponding author 
comprensión de la epigenética, identificar los elementos traza cuya toxicidad implica mecanismos epigenéticos, dilucidar el efecto de los metales traza en la epigenética de genes implicados en los mecanismos de desintoxicación y, finalmente, determinar si los daños causados por la exposición a niveles altos de elementos traza son igualmente evidentes en cualquier tejido del mismo organismo.

Los contaminantes pueden cambiar los patrones de metilación de ADN, pero no todos ellos siguen la misma ruta; ésta varía ampliamente entre grupos de metales traza o entre compuestos orgánicos. Además de la concentración y el tiempo de exposición, varios otros factores incluyendo la edad, el sexo, las fuentes de alimentos y, especialmente la fisiología de la especie, influyen en la ruta de acción de la toxicidad. Incluso dentro del mismo organismo, los patrones de metilación causados por un elemento dado varían entre los tejidos. Por lo tanto, la selección del tejido más apropiado para discernir la condición real del animal es clave para evaluar el estado real de salud de la vida silvestre. Los mecanismos epigenéticos son una herramienta importante para entender los mecanismos implicados en la toxicidad de los elementos traza, y cómo estos elementos pueden afectar los niveles de metilación del ADN. Se necesitan más estudios para caracterizar mejor las interacciones entre la metilación del ADN y los elementos traza y para dilucidar mecanismos o intervenciones potenciales que pueden ayudar a reducir sus efectos sobre la salud de la vida silvestre.

Palabras clave: contaminación, elementos traza, gen, metilación ADN, toxicidad.

Environmental pollution is a growing concern for its potential consequences on wildlife health (Shorter et al. 2012). It is common knowledge that pollution, either from anthropogenic or geochemical origin, affects wildlife; however, the specific mechanisms of action, how pollution issues should be addressed and what studies should be conducted are aspects still generally unknown. Trace elements are included among chemical contaminants. These elements are named as trace because they are commonly found in concentrations lower than $0.1 \%$ in the environment (Pais and Jones 1997) and lower than $0.01 \%$ of bodyweight in animal and plant tissues (Adriano 2001). Some trace elements (e. g. mercury) have no known biological function, while others are especially important for certain groups of organisms (e.g. boron for plants) and most are considered essential for the life of plants and animals, but might become toxic at levels above those required for each species (Templeton et al. 2000).

High levels of trace elements can be found in different parts of the world, mostly in relation with anthropogenic or geochemical activities (e.g. volcanic activity, hydrothermal sources; Amaral et al. 2007). The toxicity of trace elements will depend on the chemical form present in the environment. For example, hexavalent chromium $\left(\mathrm{Cr}^{6+}\right)$ is more toxic than the trivalent species $\left(\mathrm{Cr}^{3+}\right)$. The organic presentation of the mercury, the methylmercury is more toxic than its inorganic form (Templeton et al. 2000). Variations in toxicity of trace elements are related to the chemical form that is more easily taken up by organisms. Environmental factors such as acidification (e. g. acid rain) can increase the possibility of assimilation of metals and metalloids and, thus, their toxicity (Nordberg et al. 1985).

Toxic compounds ingested by organisms are metabolized through various detoxification mechanisms, through which they are usually biotransformed to less toxic chemical 
presentation to be excreted subsequently. Sometimes, however, depending on factors such as dose and length of exposure, biotransformation mechanisms can be exceeded, resulting in the impairment of the specimen's health (Ghoshal et al. 2000; Amaral et al. 2007). Although the early effects of pollutants in the environment can go unnoticed, these can lead to serious ecological disturbances in the long term (Baccarelli and Bollati 2009). In addition to the potential toxicity of an element at high concentrations, the effect of its interaction with other pollutants derived from anthropogenic activities such as agricultural or industrial discharges should also be taken into account.

The impact on organisms can be expressed in several ways, including chromosomal abnormalities or reduced reproductive capacity. Over time, this can undermine populations, even to the point of causing their gradual disappearance and the local extinction of one or more species (Hook and Fisher 2001; Matzuk and Lamb 2002; Choe et al. 2003; Amaral et al. 2007).

The effects of pollution on wild communities, particularly on the epigenetics of different species, such as those caused by trace metals, has lately drawn growing attention (Salnikow and Zhitkovich 2008; Arita and Costa et al. 2009; Shorter et al. 2012). However, although many of the effects in different species are well known, the specific mechanisms at work remain unknown. This is why the chronic bioaccumulation of high levels of trace elements may lead to carcinogenic (Silbergeld 2003; Waalkes 2003), teratogenic (Calevro et al. 1998) or mutagenic (Stearns et al. 2002) effects, and modify the activity of enzymes and transport proteins (Jacob et al. 2002; Amaral et al. 2007; Salnikow and Zhitkovich 2008), depending on the particular element involved. Epigenetics allows discerning how these effects take place in mammals and assess the extent of direct damage produced (Guillette and Gunderson 2001; Pilsner et al. 2010).

Rodents have been the subject of several studies examining the physiological consequences of exposure to trace elements as pollutants (Dewey and Dawson 2001; Shorter et al. 2012), including epigenetic alterations (Baccarelli and Bollati 2009; Arita and Costa 2009). These mammals have a cosmopolitan distribution and can be found in many places that are polluted as a result of anthropogenic activities, so that studies on rodents can be used as an approach of what may happen to wildlife exposed to high concentrations of one or several trace elements.

Trace elements are among the environmental factors that can affect wildlife epigenetics and thereby alter their phenotypic traits. The epigenetics concept followed hereby is the one related to meiotically and mitotically heritable changes in gene expression that are not coded in the DNA sequence itself (Levenson and Sweatt 2005). Altered patterns of gene expression can occur through a variety of mechanisms based on RNA, DNA or proteins (Egger et al. 2004).

\section{Results and}

\section{Discussion}

Epigenetic Mechanisms. DNA methylation is one of the main epigenetic mechanisms that affect chromatin structure (a highly compressed structure present in the cell nucleus composed of DNA and protein), without changing the DNA nucleotide sequence (Levenson and Sweatt 2005). This epigenetic mechanism involves the addition of a methyl group to the DNA chain, thus affecting the DNA structure and replication ability. Methylation in mammals is related to the action of a set of enzymes collectively called DNA methyltransferases 
(Okano et al. 1998). The function of these enzymes is to incorporate a methyl group at the 5 position of the pyrimidine ring of cytosine. The product is 5-methylcytosine (Chen et al. 1991), which is found in about $4 \%$ of the mammalian genomic DNA, mainly in cytosineguanine dinucleotides (CpG; Baylin 2005). Between 60 and $90 \%$ of such dinucleotides are methylated (Bird 1986); the rest of them are unmethylated and form small clusters known as cytosine-guanine islands (Levenson and Sweatt 2005). Such islands are located at the beginning or near the promoter regions in about $50 \%$ of all mammalian genes, where DNA transcription starts (Bird 1986; Antequera and Bird 1993). Under normal conditions, the vast majority of these islands are unmethylated (Antequera and Bird 1999). Methylation in the promoter region of a gene silences its expression (Jacob et al. 2002). An imbalance in methylation patterns can cause either hypo- or hypermethylation relative to the species' normal DNA methylation level.

Factors influencing methylation patterns. Methylation patterns and levels vary both between organisms and between tissues within the same individual. In the animal kingdom, species range from a) those whose genome lacks any detectable level of methylated cytosine (e.g. the worm Caenorhabditis elegans; Bird 2002) because it does not encode DNA methyltransferase; b) those containing very low methylation levels, basically constrained to dinucleotides formed by cytosine and thymine instead of cytosine and guanine (the fruit fly Drosophila melanogaster; Gowher et al. 2000; Bird 2002); and c) those having an extensively methylated genome, as is the case of vertebrates. Birds and mammals have similar methylation levels, which are lower than those found in fish and amphibians. This has been related to body temperature and, thus, to evolutionary processes (Varriale 2014).

The individual's age is an important variable in epigenetic processes. In mammalian somatic cells, the levels of 5-methylcytosine may show temporal and spatial variations. During the early development stages, rodents show a significant reduction in methylation levels, decreasing to around $30 \%$ of their typical somatic level of methylation in adults (Monk et al. 1987; Kafri et al. 1992; Bird 2002). This implies that virtually no gene is silenced and all of them can be expressed. It is in the early stages of development when the regulation occurs as to which genes are expressed and which are not. The silencing process is carried out through methylation, by means of the methyltransferase family of enzymes (DNMT). This family of enzymes includes isoforms DNMT1, DNMT3a and DNMT3b. During rodent development, DNMT1 appears to be responsible for maintaining the species-specific DNA methylation patterns, whereas DNMT3a and DNMT3b are involved in the establishment of new embryonic methylation patterns (Okano et al. 1999; Bestor 2000; Baylin 2005). Therefore, the latter two isoforms will be responsible for achieving the level of silenced genes observed in the adult and which existed at the time of implantation (Okano et al. 1998, 1999; Bird 2002). However, this process does not take place in all animal species; for example, in the zebrafish (Danio rerio; MacLeod et al. 1999) no decrease in methylation levels is observed during embryonic development. These variations between species reflect the role that DNA methylation plays in each organism. In mammals, the demethylation cycle followed by de novo methylation during the early embryonic stages is critical in determining somatic DNA methylation patterns, which will be stable and inheritable as a clonal methylation pattern (Mesa-Cornejo et al. 2006).

Another factor to consider is the organism's sex, as it has been observed that pollutants 
can differentially affect methylation patterns in males and females of the same species. In male polar bears (Ursus maritimus), an inverse relationship between mercury exposure and DNA methylation levels in the lower brainstem has been recorded. These changes are related to DNA hypomethylation and, consequently, lead to changes in long-term chromosomal stability, thus underlying the development of autoimmune diseases and affecting reproduction, which has not been observed in females (Pilsner et al. 2010).

Effects on reproduction. The environment also affects the reproductive success of animal species. The area inhabited by females live prior to conception and during early pregnancy affects oocyte development and the early embryonic stages. Nutrition is one of the most critical environmental factors in this stage. Alterations in food quantity and composition affect oocyte maturation, gastrulation, and even embryo survival. In this regard, one aspect worth noting is the influence of diet on the methylation patterns of numerous genes (Ashworth et al. 2009). The diet provides the methyl groups that will be used in the process and will be associated with the imprint or "methylation marks" involved in silencing a gene. Examples are all the mechanisms involved in the inactivation of one of the mother's two $\mathrm{X}$ chromosomes and the parentally imprinted genes. Genomic imprinting is the process by which one of the two parental genes is silenced, leaving only one active. Most genes in diploid organisms are expressed regardless of their parental origin. However, a few genes (approximately 100) are regulated and transcribed in a monoallelic fashion. For these genes, called imprinted (or marked) genes, the expression and regulation pattern depends on their parental origin. That is, they behave differently if they are of paternal or maternal origin (Reik 2007; Reig and Concha 2012). Any error during this delicate process may lead to either the two parental genes being expressed or none of them, thereby altering the phenotype and resulting in various diseases, some of which might be lethal. Although methylation patterns are stable and inheritable at the genomic level, there are at least two embryonic development stages where the global methylation pattern is erased and reset: the generation of germ cells and the embryonic implantation period (Reik et al. 2001). This is one of the major processes in which methylation is involved, enabling or silencing gene expression. For this process to take place, mammals must get methyl groups from food since these cannot be synthesized. Consequently, the diet should contain methionine, choline, and cofactors such as folic acid and pyridoxines, all being substances that supply methyl groups (Kaminker 2007).

Effect of trace elements on DNA methylation patterns. The presence of pollutants in the diet, particularly trace metals, can disrupt DNA methylation patterns. Trace elements such as cadmium, chromium, nickel, arsenic and mercury have been found to cause neurodegenerative disorders, and can also act as endocrine disrupters. That is, they interfere with the biosynthesis of hormones, as well as with their metabolism and activity, leading to the loss of homeostasis of the endocrine-reproductive system (Baccarelli and Bollati 2009; Diamanti-Kandarakis et al. 2009).

Pollutant concentration and time of exposure have been generally related, among other things, to the hypomethylation of a number of genes. This effect directly results in a low survival rate and prematurity, as well as on post-natal growth problems (Ashworth et al. 2009; Shutoh et al. 2009). 
DNA hypomethylation and hypermethylation are attributed to several factors, including various environmental agents such as exposure to above-normal concentrations of trace elements such as copper, chromium, lead, nickel, cadmium and arsenic (Tkeshelashvili et al. 1991; Silbergeld 2003; Salnikow and Zhitkovich 2008; Arita and Costa 2009). Except for chromium, which forms stable adducts with DNA, the other elements are considered as very weak mutagens (Takiguchi et al. 2003; Arita and Costa 2009). These elements can directly act as genotoxic agents, but in-vitro tests have shown that elements such as cadmium require such high doses that impair cell growth (Misra et al. 1998); therefore, it is still unclear how this could happen in vivo (Takiguchi et al. 2003). Another possibility is the indirect effect of trace elements on the accuracy of the DNA replication process and impairment of apoptosis (Pulido and Parrish, 2003; Arita and Costa 2009).

It is known that cadmium toxicity partially derives from its being a common inhibitor of enzymes, including DNA-methyltransferase. At the concentrations needed for this metal to inhibit up to $84 \%$ of this enzyme activity in rat liver cells, other elements such as zinc, nickel, lead and arsenic do not affect the activity of this enzyme in the same type of cell lines (Takiguchi et al. 2003). The complexity of cadmium toxicity is further evidenced by the observation that at the beginning of the inhibition of the DNA methyltransferase activity, DNA hypomethylation occurs. However, under chronic cadmium exposure, cells undergo a morphological transformation that promotes cell proliferation and a significant increase in the activity of DNA methyltransferase, which leads to DNA hypermethylation (Takiguchi et al. 2003). Out of 1,629 genes exposed to cadmium, 675 (41.44\%) showed hypermethylation, 899 (55.19 \%) hypomethylation, and 55 (3.38\%) a mixture of hyper- and hypomethylation in the cytosine - guanine islands of their promoter regions (Wang et al. 2012b). An overall hyper- or hypomethylation will reflect a pool of genes with different methylation levels. This explains why cells exposed for short periods of time show hypomethylation by not having accumulated sufficient methylated genes, whereas cells exposed to cadmium for longer periods of time show DNA hypermethylation due to the larger number of methylated genes (Wang et al. 2012a).

Unlike cadmium, nickel can simultaneously inhibit the activity of DNA methyltransferase and cause DNA hypermethylation (Lee et al. 1998). A mechanism proposed to explain this phenomenon includes the ability of this element to replace magnesium in the phosphate backbone of DNA in heterochromatin. Magnesium replacement takes place in heterochromatin because of the higher magnesium concentration therein relative to euchromatin. The replacement of magnesium by nickel increases heterochromatin condensation, which in turn will trigger the de-novo methylation of DNA in critical genes, such as those associated with tumour suppression or senescent genes (Lee et al. 1995; Arita and Costa 2009).

Another mechanism by which trace elements may also alter methylation patterns is the reduction of S-adenosylmethionine levels. This coenzyme is the main donor of methyl groups in living organisms and is therefore required for all cellular methylation reactions. The deficiency of methyl donor compounds, such as folic acid, in the diet may also impair the synthesis of S-adenosylmethionine. As levels of this metabolite decrease in cells, various methylation processes become compromised. One example is the arsenic detoxification process that takes place to eliminate this metal from the organism. In the environment, arsenic commonly occurs as either arsenate $\left(\mathrm{As}^{+5}\right)$ or arsenite $\left(\mathrm{As}^{+3}\right)$, the latter being the 
more toxic form, often associated with cancer risk (Bertolero et al. 1987). Arsenic enters the body primarily as arsenite by simple diffusion. By contrast, only a small portion of arsenate will be able to cross cell membranes, as this requires an energy-dependent active transport system. Arsenite accumulates within cells more readily than arsenate which, in any case, will also be converted to arsenite by a reduction reaction in which glutathione plays a key role (Salnikow and Zhitkovich 2008).

The elimination of arsenite from the organism requires its methylation through a series of reactions catalyzed by the cytosolic arsenic $\left({ }^{+3}\right)$ methyltransferase. This arsenic-methylation reaction, that uses S-adenosylmethionine as a methyl donor (Thomas et al. 2007) reduces the amount of S-adenosylmethionine that is available in the organism, thus impairing the natural gene-silencing methylation process, hence leading to the expression of genes that would otherwise be silenced.

In rodents, it has been found that the consumption of high folate levels helps reduce total arsenic content in the liver of pregnant females, but does not prevent the effects of exposure to inorganic arsenic on foetuses weight or hepatic S-adenosylmethionine concentrations. Foetuses exposed only to arsenic showed a slight effect on the DNA methylation pattern in their liver, in contrast to those exposed to both arsenic and folate, which showed changes in the methylation patterns of the cytosine-guanine islands of 2,931 genes, several of the which are associated with neurological development, cancer, cell cycles and signaling networks; the biological pathways worst affected include the one regulating foetal development (Tsang et al. 2012).

However, the presence of tumours associated with prolonged arsenic exposure has also been related to other mechanisms. One of those is the modification of histones of the promoter region of the p16 tumour-suppressor gene, which suppresses the expression of this gene and leads to a higher incidence of tumours, as observed in mice supplied with water containing inorganic arsenate for 6 months (Suzuki and Nohara 2012).

Another likely mechanism is the effect of arsenic on the expression of genes involved in lipid metabolism in the liver, which leads to an increase in lipogenesis and the intracellular accumulation of triglycerides in this tissue. This process is believed to play a key role in tumorigenesis, as it favours the increase of oxidative stress that can cause DNA damage and, thus, genetic mutations that are commonly expressed as tumour formation (Nohara et al. 2012).

Effects of trace elements on the methylation patterns of genes involved in detoxification systems. The elimination of trace elements from the body may be impaired when the activity of any of the enzymes involved in the process, such as the DNA methyltransferase in the case of arsenic elimination, is affected. Metallothioneins are another family of proteins that play a key role in detoxification processes of elements such as cadmium. These, low-molecular weight cysteine-rich proteins, play an important role in the homeostasis of divalent metals, in addition to being responsible for reducing their toxicity. This is achieved by binding metals via sulfhydryl groups (Heuchel et al. 1994). In most mammals, metallothioneins occur in four isoforms: MT-I, MT-II, MT-III and MT-IV. The first two isoforms are expressed in all tissues, MT-III is expressed only in the brain and MT-IV is only present in the stratified squamous epithelium of the skin, the tongue and the upper gut (Aschner et al. 1997). In most tissues, MT-I and MT-II levels are deemed negligible, but can rise dramatically by a variety of agents, 
including exposure to metals, ultraviolet radiation and agents producing reactive oxygen species. Basal levels of MT-I and MT-II, as well as levels induced by the presence of metals, are mediated by the Metal-Responsive Transcription Factor MTF-1 (Heuchel et al. 1994; Giedroc et al. 2001; Wimmer et al. 2005). MTF-1 has been maintained throughout evolution in humans (Brugnera et al. 1994), mice (Radtke et al. 1993), fish (Maur et al. 1999) and even in the fruit fly (Zhang et al. 2001). In both lymphosarcoma cells and rodent hepatomas, the cytosine-guanine islands in the promoter region of the MT-1 gene have been found to be completely methylated and, thus, the transcription of this metallothionein is silenced; the reason of this remains unknown. However, also observed is that when the promoter region of the MT-1 gene is demethylated —and is, therefore, overexpressed-, MT-1, either alone or in combination with other factors, may suppress the growth of some tumours (Ghoshal et al. 2002). The Metal-Responsive Transcription Factor is also essential for liver development in embryos, as well as for the completion of pregnancy. By contrast, during adulthood it is not essential and its deficiency does not lead to death (Wimmer et al. 2005).

No induction of the gene encoding MT-1 occurs in rat hepatomas and mouse lymphosarcomas. This is because most cytosines are methylated in $\mathrm{CpG}$ dinucleotides present in the promoter region of the gene. In hepatomas, the maintenance activity as denovo DNA methyltransferases $3 \mathrm{a}$ and $3 \mathrm{~b}$ is three to six times as high as in the liver of animals where the MT-1 gene has no methylated cytosines. The same pattern was observed in the liver and thymus of animals with hepatomas and lymphosarcoma (Jacob et al. 2002). The fact the same gene is not induced in one tissue (e.g. tumour) while it is in the tissue of an adjacent organ (e.g. liver), has been attributed to the intervention of methylation promoters in the diseased tissue (Waalkes et al. 1996; Jacob et al. 2002).

A given pollutant preventing the expression of a gene associated with a detoxification mechanism does not mean that the same happens to other genes also involved in the elimination of toxic substances from the body. In the cellular detoxification process, there are protein families other than metallothioneins that also participate in the removal of pollutants or noxious substances from cells. These include Glutathione S-Transferases (GSTs), which are a group of enzymes involved in the elimination of endogenous compounds, as well as of environmental pollutants and drugs. GST levels increase in the presence of products derived from oxidative stress and inflammatory processes caused by trace elements in above-normal concentrations in the organism, among other reasons. This is why the gene encoding Glutathione S-Transferase (GSTP1) has been proposed as a "caregiver" gene (Nakayama et al. 2004). Hypermethylation of the GSTPI gene -and, therefore, its inactivation - has been associated with various forms of cancer, and occurs in over $70 \%$ of high-grade intraepithelial neoplasias.

In rodent hepatoma and lymphosarcoma, it has been observed that when GSTP1 is activated, MT-1 is not. Conversely, MT-1 was induced by cadmium in tumours in which GSTP1 is suppressed due to methylation of the promoter. The mechanism involved is highly complex, as the lack of MT-1 is due to two reasons: the methylation of the transcription factor (MTF-1, as previously mentioned), without which the gene cannot be expressed; and an increased activity of the repressors of this gene, including the Nuclear Factor I (NFl; Majumder et al. 2001; Jacob et al. 2002). Also important is that, paradoxically, tumoursuppressor genes such as p53 and p16 are expressed in these same cancer cells (Jacob et al. 2002), which would be expected to be suppressed in these cells. Among all these 
mechanisms, the potential importance of MT-1 as tumour suppressors is worth noting, in addition to their important role in metal homeostasis.

The evidence summarized above shows that exposure to contamination levels of trace elements can alter the overall DNA methylation patterns, depending on the number of genes that are affected and become either over- or under-expressed, or even silenced. However, it should be stressed that, in most cases, the effect of trace elements is not associated with mutations but with epigenetic processes. In rodents, over 200 genes have been associated with reproductive impairment, including chromosomal aberrations and infertility (Matzuk and Lamb 2002), when these are damaged by some factor, including exposure to pollutants. This highlights the importance of considering changes in DNA methylation patterns as a result of the toxic effects of trace elements, and of including this approach in environmental studies.

\section{Acknowledgements}

This article is one of the outcomes of the author's stay at the University of California, Berkeley, made possible by a grant from CONACyT $(203952,151189)$. The authors are grateful to Maria Elena Sanchez Salazar whom provided valuable editorial services.

\section{Literature cited}

Adriano, D. C. 2001. Trace elements in terrestrial environments: biogeochemistry, bioavailability, and risks of metals. Springer. New York, New York, EE. UU.

Amaral, A., C. Cabral, Guedes, C., and A. Rodrigues. 2007. Apoptosis, metallothionein, and bioavailable metals in domestic mice (Mus musculus L.) from a human-inhabited volcanic area. Ecotoxicology 16:475-482.

Antequera, F., And A. Bird. 1993. Number of CpG islands and genes in human and mouse. Proceedings of the National Academy of Sciences 90:11995-11999.

Antequera, F., AND A. Bird. 1999. CpG islands as genomic footprints of promoters that are associated with replication origins. Current Biology 9:R661-R667.

Arita, A., And M. CostA. 2009. Epigenetics in metal carcinogenesis: nickel, arsenic, chromium and cadmium. Metallomics 1:222-228.

Aschner, M., M. G. Cherian, C. D. Klaassen, R. D. Palmiter, J. C. Erickson, and A. I. Bush. 1997. Metallothioneins in brain-the role in physiology and pathology. Toxicology and applied pharmacology 142:229-242.

Ashworth, C. J., L. M. Toma, And M. G. Hunter. 2009. Nutritional effects on oocyte and embryo development in mammals: implications for reproductive efficiency and environmental sustainability. Philosophical Transactions of the Royal Society B: Biological Sciences 364:3351-3361.

Baccarelli, A., and V. Bollatı. 2009. Epigenetics and environmental chemicals. Current Opinion in Pediatrics 21:243-251.

Baylin, S. B. 2005. DNA methylation and gene silencing in cancer. Nature Clinical Practice Oncology 2:S4-S11.

Bertolero, F., G. Pozzi, E. Sabbioni, and U. Saffiottı. 1987. Cellular uptake and metabolic reduction of pentavalent to trivalent arsenic as determinants of cytotoxicity and morphological transformation. Carcinogenesis 8:803-808.

Bestor, T. H. 2000. The DNA methyltransferases of mammals. Human Molecular Genetic 
9:2395-2402.

Bird, A. P. 1986. CpG-rich islands and the function of DNA methylation. Nature 321:209213.

BIRD, A. 2002. DNA methylation patterns and epigenetic memory. Genes and Development 16:6-21.

Brugnera, E., O. Georgiev, F. Radtke, R. Heuchel, E. Baker, G. R. Sutherland, and W. Schaffner. 1994. Cloning, chromosomal mapping and characterization of the human metalregulatory transcription factor MTF-1. Nucleic Acids Research 22:3167-3173.

Calevro, F., S. Campani, M. Ragghianti, S. Buccl, and G. Mancino. 1998. Tests of toxicity and teratogenicity in biphasic vertebrates treated with heavy metals $\left(\mathrm{Cr}^{3+}, \mathrm{Al}^{3+}, \mathrm{Cd}^{2+}\right)$. Chemosphere 37:3011-3017.

Chen, L., A. M. MacMillan, W. Chang, K. Ezaz-Nikpay, W. S. Lane, and G. L.Verdine. 1991. Direct identification of the active-site nucleophile in a DNA (cytosine-5)-methyltransferase. Biochemistry 30:11018-11025.

Choe, S. Y., S. J. Kıм, H. G. Kım, J. H. Lee, Y. Chol, H. Lee, And Y. Kıм. 2003. Evaluation of estrogenicity of major heavy metals. Science of the Total Environment 312:15-21.

Dewey, M. J., and W. D. Dawson. 2001. Deer mice: "The Drosophila of North American mammalogy". Genesis 29:105-109.

Diamanti-Kandarakis, E., J. P. Bourguignon, L. C. Giudice, R. Hauser, G. S. Prins, A. M. Soto, Zoeller, T. R., ANd A. C. Gore. 2009. Endocrine-disrupting chemicals: an Endocrine Society scientific statement. Endocrine Reviews 30:293-342.

Egger, G., G. Liang, A. Aparicio, and P. A. Jones. 2004. Epigenetics in human disease and prospects for epigenetic therapy. Nature 429:457-463.

Ghoshal, K., S. Majumder, Z. LI, X. Dong, And S. T. Jacob. 2000. Suppression of metallothionein gene expression in a rat hepatoma because of promoter-specific DNA methylation. Journal of Biological Chemistry 275:539-547.

Ghoshal, K., J. Datta, S. Majumder, S. Bai, X. Dong, M. Parthun, and S. T. Jacob. 2002. Inhibitors of histone deacetylase and DNA methyltransferase synergistically activate the methylated metallothionein I promoter by activating the transcription factor MTF-1 and forming an open chromatin structure. Molecular and Cellular Biology 2:8302-8319.

Giedroc, D. P., X. Chen, And J. L. Apuy. 2001. Metal response element (MRE)-binding transcription factor-1 (MTF-1): structure, function, and regulation. Antioxidants and Redox Signaling 3:577-596.

Gowher, H., O. Leismann, And A. Jeltsch. 2000. DNA of Drosophila melanogaster contains 5-methylcytosine. The European Molecular Biology Organization Journal 19:69186923.

Guillette, L. J., And M. P. Gunderson. 2001. Alterations in development of reproductive and endocrine systems of wildlife populations exposed to endocrine-disrupting contaminants. Reproduction 122:857-864.

Heuchel, R., F. Radtke, O. Georgiev, G. Stark, M. Aguet, and W. Schaffner. 1994. The transcription factor MTF-1 is essential for basal and heavy metal-induced metallothionein gene expression. The European Molecular Biology Organization Journal 13:2870-2875.

Hook, S. E., AND N. S. Fisher. 2001. Reproductive toxicity of metals in calanoid copepods. Marine Biology 138:1131-1140. 
Jacob, S. T., S. Majumder, and K. Ghoshal. 2002. Suppression of metallothionein-I/ II expression and its probable molecular mechanisms. Environmental Health Perspectives 110:827-830.

Kafri, T., M. Ariel, M. Brandeis, R. Shemer, L. Urven, J. McCarrey, H. Cedar, and A. Razin. 1992. Developmental pattern of gene-specific DNA methylation in the mouse embryo and germ line. Genes and Development 6:705-714.

KaminkeR, P. 2007. Epigenética, ciencia de la adaptación biológica heredable. Archivos Argentinos de Pediatría 105:529-531.

Lee, Y.W., C. B. Klein, B. Kargacin, K. Salnikow, J. Kitahara, K. Dowjat, A Zhitkovich, N. T. Christie, AND M. Costa. 1995. Carcinogenic nickel silences gene expression by chromatin condensation and DNA methylation: a new model for epigenetic carcinogens. Molecular and Cellular Biology 15:2547-2557.

Lee, Y. W., L. Broday, AND M. Costa. 1998. Effects of nickel on DNA methyltransferase activity and genomic DNA methylation levels. Mutation Research/Genetic Toxicology and Environmental Mutagenesis 415:213-218.

Levenson, J. M., And J. D. Sweatt. 2005. Epigenetic mechanisms in memory formation. Nature Reviews Neuroscience 6:108-118.

Macleod, D., V. Clark, and A. Bird. 1999. Absence of genomewide changes in DNA methylation during development of the zebrafish (Danio rerio). Nature Genetics 23:139-140.

Majumder, S., K. Ghoshal, R. M. Gronostajski, and S. T. Jacob. 2001. Downregulation of constitutive and heavy metal-induced metallothionein-l expression by nuclear factor I. Gene Expression 9:203-215.

Matzuk, M. M., And D. J. Lamb. 2002. Genetic dissection of mammalian fertility pathways. Nature Cell Biology and Nature Medicine 4:S41-S49.

Maur, A., T. Belser, G. Elgar, O. Georgiev, and W. Schaffner. 1999. Characterization of the transcription factor MTF-1 from the Japanese pufferfish (Fugu rubripes) reveals evolutionary conservation of heavy metal stress response. Biological Chemistry 380:175-185.

Mesa-Cornejo, V. M., P. Barros-Núñez, and C. Medina-Lozano. 2006. Metilación del ADN: marcador diagnóstico y pronóstico de cáncer. Gaceta Médica de México 142:81-82.

MisRa, R. R., G. T. Smith, ANd M. P. WaAkes. 1998. Evaluation of the direct genotoxic potential of cadmium in four different rodent cell lines. Toxicology 126:103-114.

Monk, M., M. Boubelik, And S. Lehnert. 1987. Temporal and regional changes in DNA methylation in the embryonic, extraembryonic and germ cell lineages during mouse embryo development. Development 99:371-382.

Nakayama, M., M. L. Gonzalgo, S. Yegnasubramanian, X. Lin, A .M. De Marzo, and W. G. Nelson. 2004. GSTP1 CpG island hypermethylation as a molecular biomarker for prostate cancer. Journal of Cellular Biochemistry 91:540-552.

Nohara, K., Y. Tateishi, T. SuzUki, K. Okamura, H. Mural, S. Takumi, F. Maekawa, M. Nishimura, M. KoBORI, AND T. Iто. 2012. Late-onset increases in oxidative stress and other tumorigenic activities and tumors with a Ha-ras mutation in the liver of adult male $\mathrm{C} 3 \mathrm{H}$ mice gestationally exposed to arsenic. Toxicological Sciences 129:293-304.

NordberG, G. F., R. A. Goyer, And T. W. Clarkson. 1985. Impact of effects of acid precipitation on toxicity of metals. Environmental Health Perspectives 63:169-180. 
OKano, M., S. XIE, AND E. Ll. 1998. Cloning and characterization of a family of novel mammalian DNA (cytosine-5) methyltransferases. Nature Genetics 19:219-220.

Okano, M., D. W. Bell, D. A. Haber, And E. Lı. 1999. DNA methyltransferases Dnmt3a and Dnmt3b are essential for de novo methylation and mammalian development. Cell 99:247-257.

PaIS, I., AND J. B. Jones JR. 1997. The handbook of trace elements. CRC Press. Boca Raton, EE. UU.

Pilsner, R. J., A. L. Lazarus, D. H. Nam, R. J. Letcher, C. Sonne, R. Dietz, and N. Basu. 2010. Mercury-associated DNA hypomethylation in polar bear brains via the LUminometric Methylation Assay: a sensitive method to study epigenetics in wildlife. Molecular Ecology 19:307-314.

Pulido, M. D., And A. R. Parrish. 2003. Metal-induced apoptosis: mechanisms. Mutation Research/Fundamental and Molecular Mechanisms of Mutagenesis 533:227-241.

Radtke, F., R. Heuchel, O. Georgiev, M. Hergersberg, M. Gariglio, Z. Dembic, and W. Schaffner. 1993. Cloned transcription factor MTF-1 activates the mouse metallothionein I promoter. The European Molecular Biology Organization Journal 12:1355-1362.

ReiG, G., AND M. L. Concha. 2012. Impronta Genómica y Desarrollo Embrionario. International Journal of Morphology 30:1453-1457.

Reik, W., W. Dean, and J. Walter. 2001. Epigenetic reprogramming in mammalian development. Science 293:1089-1093.

REıK, W. 2007. Stability and flexibility of epigenetic gene regulation in mammalian development. Nature 447:425-432.

Salnikow, K., and A. Zhiтkovich. 2008. Genetic and epigenetic mechanisms in metal carcinogenesis and cocarcinogenesis: nickel, arsenic, and chromium. Chemical Research in Toxicology 21:28-44.

Shorter, K. R., J. P. Crossland, D. Webb, G. Szalai, M. R. Felder, and P. B. Vrana. 2012. Peromyscus as a mammalian epigenetic model. Genetics Research International 2012(179159):1-11.

Shutoh, Y., M. Takeda, R. Ohtsuka, A. Haishima, S. Yamaguchi, H. Fujie, Y. Komatsu, K. Maita, AND T. Harada. 2009. Low dose effects of dichlorodiphenyltrichloroethane (DDT) on gene transcription and DNA methylation in the hypothalamus of young male rats: implication of hormesis-like effects. The Journal of Toxicological Sciences 34: 469482.

Silbergeld, E. K. 2003. Facilitative mechanisms of lead as a carcinogen. Mutation Research/ Fundamental and Molecular Mechanisms of Mutagenesis 533:121-133.

Stearns, D. M., S. M. Silveira, K. K. Wolf, and A. M. Luke. 2002. Chromium (III) tris (picolinate) is mutagenic at the hypoxanthine (guanine) phosphoribosyltransferase locus in Chinese hamster ovary cells. Mutation Research/Genetic Toxicology and Environmental Mutagenesis 513:135-142.

Takiguchi, M., W. E. Achanzar, W. Qu, G. LI, and M. P. Waalkes. 2003. Effects of cadmium on DNA-(Cytosine-5) methyltransferase activity and DNA methylation status during cadmium-induced cellular transformation. Experimental Cell Research 286:355-365.

Templeton, D. M., F. Ariese, R. Cornelis, R., L. G. Danielsson, H. Muntau, H. P. Van Leeuwen, and R. LoBINskı. 2000. Guidelines for terms related to chemical speciation and fractionation of elements. Definitions, structural aspects, and methodological approaches (IUPAC 
Recommendations 2000). Pure and Applied Chemistry 72:1453-1470.

Thomas, D. J., J. LI, S. B. Waters, W. Xing, B. M. Adair, Z. Drobna, V. Devesa, And M. Styblo. 2007. Arsenic (+ 3 oxidation state) methyltransferase and the methylation of arsenicals. Experimental Biology and Medicine 232:3-13.

TKeshelashvili, L. K., T. McBride, K. Spence, and L. A. Loeb. 1991. Mutation spectrum of copperinduced DNA damage. Journal of Biological Chemistry 266:6401-6406.

Tsang, V., R. C. Fry, M. D. Niculescu, J. E. Rager, J. Saunders, D. S. Paul, S. H. Zeisel, M. P. Waalkes, M. StÝblo, and D. Drobná. 2012. The epigenetic effects of a high prenatal folate intake in male mouse fetuses exposed in utero to arsenic. Toxicology and Applied Pharmacology 264:439-450.

Varriale, A. 2014. DNA methylation, epigenetics, and evolution in vertebrates: facts and challenges. International Journal of Evolutionary Biology 2014(475981):1-7.

Waalkes, M. P., B. A. Diwan, S. Rehm, J. M. Ward, M. Moussa, M. G. Cherian, and R. A. Goyer. 1996. Down-regulation of metallothionein expression in human and murine hepatocellular tumors: association with the tumor-necrotizing and antineoplastic effects of cadmium in mice. Journal of Pharmacology and Experimental Therapeutics 277:1026-1033.

WaAlkes, M. P. 2003. Cadmium carcinogenesis. Mutation Research/Fundamental and Molecular Mechanisms of Mutagenesis 533:107-120.

Wang, B., Y. LI, C. Shao, Y. Tan, And L. CAI. 2012a. Cadmium and its epigenetic effects. Current medicinal chemistry 19:2611-2620.

Wang, B., Y. LI, Y. Tan, X. Miao, X.D. Liu, C.X. Shao, H. Yang, S. Turdi, L. J. Ma, J. Ren, and L. CAl. 2012b. Low-dose Cd induces hepatic gene hypermethylation, along with the persistent reduction of cell death and increase of cell proliferation in rats and mice. PloS One 7:e33853.

Wimmer, U., Y. Wang, O. Georgiev, and W. Schaffner. 2005. Two major branches of anticadmium defense in the mouse: MTF-1/metallothioneins and glutathione. Nucleic Acids Research 33:5715-5727.

Zhang, B., D. Egli, O. Georgiev, and W. Schaffner. 2001. The Drosophila homolog of mammalian zinc finger factor MTF-1 activates transcription in response to heavy metals. Molecular and Cellular Biology 21:4505-4514.

Sometido: 11 de septiembre de 2014

Revisado: 1 de octubre de 2014

Aceptado: 14 de noviembre de 2014

Editor asociado: Consuelo Lorenzo 
TRACE ELEMENTS AND DNA METHYLATION

830 THERYA Vol.5(3): 817-829 